\title{
Memosisikan Bahasa Inggris dalam Perencanaan Bahasa di Indonesia
}

\author{
Yani Adyawardhani \\ Jurusan Bahasa Inggris, Politeknik Negeri Bandung, Indonesia \\ Email: yani.adya@polban.ac.id
}

\begin{abstract}
RINGKASAN
Kajian ini mendiskusikan pemakaian Bahasa Inggris di kalangan penutur Bahasa Indonesia di lingkungan kita sehari-hari. Ada kecenderungan di beberapa kalangan seperti para professional di bidang kuliner, para pemimpin, dan para kawula muda untuk menggunakan Bahasa Inggris bercampur aduk dengan pemakaian Bahasa Indonesia (BI) bahkan untuk ungkapan dan kata-kata yang ada padanannya dalam BI mereka lebih mendahulukan menggunakan Bahasa Inggris. Dari sudut pandang perencanaan bahasa perlu ada pertimbangan dan kajian kembali tentang peran dan fungsi Bahasa Inggris yang hingga saat ini dianggap sebagai salah satu bahasa asing utama untuk komunikasi internasional dan kemajuan ilmu pengetahuan (Huda, 1999; Alwi \& Sugono, 2003). Dengan mengacu kepada pengalaman perencanaan bahasa di beberapa negara, Indonesia perlu meneteapkan suatu kebijakan bahasa yang akan meninjau dan menata ulang pemakaian Bahasa Inggris dalam kehidupan bermasyarakat agar dapat memberikan manfaat bagi perkembangan ilmu, teknologi dan Bahasa Indonesia sendiri.
\end{abstract}

Kata Kunci: pengaruh Bahasa Inggris terhadap Bahasa Indonesia, perencanaan bahasa di Indonesia

\begin{abstract}
This article discusses the use of English language among Bahasa Indonesia speakers in their everyday activities. It is learned that there is a tendency of using a mixture of English and Bahasa Indonesia the communication among the practitioners of culinary, formal leaders, and young people. They use English for words which actually have their words (padanan) in Bahasa Indonesia, and they decide to use the English version rather than its original in Bahasa Indonesia. From the point of view of language planning, there needs to be a further consideration and study on the role and function of the English language in Indonesia which is currently considered as one of the main foreign languages to be used in international communication and to further knowledge (Huda, 1999; Alwi \& Sugono, 2003). Referring to the language planning experience of several country, Indonesia needs to determine a language policy that will look at and redesign the use of English in the lives of people so that it helps further knowledge and technology and Bahasa Indonesia itself.
\end{abstract}

Key words: the influence of English language on Bahasa Indonesia, language planning in Indonesia.

\section{PENDAHULUAN}

Kebijakan bahasa negara-negara yang baru lepas dari kolonialisme bangsa penjajahnya menetapkan adanya satu bahasa sebagai bahasa nasional sebagai bentuk identitas dan bahasa pemersatu, terutama bagi negara yang multietnik. Adanya satu 
bahasa nasional untuk satu negara merupakan salah satu ciri negara modern; dalam perkembangan selanjutnya negara akan mempertimbangkan perlunya satu bahasa asing terutama pada masa globalisasi yang menuntut negara dan masyarakatnya untuk melakukan hubungan dengan negara lain. Indonesia sebagai salah satu negara multietnik, sejak tahun 1928 telah menetapkan satu bahasa nasional yang mempersatukan dan sekaligus memberikan identitas bagi berbagai etnik yang tersebar di seluruh nusantara sebagai masyarakat yang berbangsa satu, bangsa Indonesia, dan berbahasa satu yaitu Bahasa Indonesia. Akan tetapi apakah penggunaan bahasa asing (dalam hal ini bahasa Inggris) disamping bahasa nasional sesuai fungsinya sebagai bahasa yang membuka peluang komunikasi internasional serta membuat bangsa menjadi lebih maju baik di bidang politik, ekonomi, dan pendidikan, sosial dan budaya? Dalam tulisan ini akan dibahas pengaruh Bahasa Inggris dalam aktivitas sosial, professional, dan pendidikan pada umumnya; serta bagaimana kecenderungan pemakaian Bahasa Inggris ini dilihat dari sudut perencanaan Bahasa.

\section{Bahasa Inggris di Indonesia}

Pergaulan dengan bangsa-bangsa di dunia dan perkembangan globalisasi membuat batas-batas negara menjadi tipis; setiap negara termasuk Indonesia membuat kebijakan mengadopsi pemakaian bahasa asing yang dapat meningkatkan kualitas komunikasi antar bangsa. Hingga saat ini bahasa Inggris masih tetap menjadi pilihan berbagai negara untuk tujuan komnikasi antar bangsa tersebut. Banyak bangsa-bangsa di Asia menetapkan bahasa Inggris sebagai salah satu bahasa asing yang mendampingi bahasa nasionalnya. Dengan demikian, pengaruh yang terjadi dalam komunikasi masyarakat di negara-negara tersebut cukup signifikan. Kirkpatrick dan Sussex (2012:3) menengarai "... There is no country inAsia where English is not the first language after the national language... "tidak ada satu negara pun di Asia yang tidak menempatkan bahasa Inggris setelah bahasa nasionalnya. Dengan status bahasa Inggris seperti ini, terutama di negara-negara ASEAN, pencampuradukan (code mixing) antara bahasa Inggris dan bahasa nasionalnya dianggap oleh Kirkpatrick dan Sussex (2012) sebagai sesuatu yang alami, dan menjadi strategi kreatif untuk menjadikannya penanda identitas. 
Indonesia pun mengalami hal yang sama seperti yang ditengarai oleh Kirkpatrick dan Sussex (2012). Kebijakan menetapkan bahasa Inggris sebagai bahasa asing di Indonesia telah menyebabkan meluasnya pemakaian termasuk pengajaran dan pembelajaran bahasa tersebut. Walaupun tidak menjadi bahasa kedua, tetapi bagi sebagian masyarakat Indonesia berbahasa Inggris telah menjadi hal yang umum; bahkan dalam banyak kesempatan yang berhubungan dengan pekerjaan atau kegiatan sosial, Bahasa Indonesia dicampuradukkan dengan Bahasa Inggris. Walaupun Kirkpatrick dan Sussex (2012) menganggap itu adalah hal yang alami dan mempunyai efek positif, keadaan ini harus diakui menghasilkan Bahasa Indonesia yang tidak utuh.

Bahasa Inggris di Indonesia, sebagai salah satu bahasa asing utama, mempunyai dua fungsi (Huda, 1999:70-71). Pertama, sebagai alat komunikasi global yang mendukung pemakaian bahasa Indonesia dalam semua aspek komunikasi dengan bangsa dan negara lain seperti antara lain dalam pengembangan kebijakan luar negeri; dan kedua, sebagai alat dalam proses pembangunan yaitu dalam "... pemanfaatan dan pengembangan iptek ...". Lebih jau h Huda (1999) menyebutkan bahwa fungsi bahasa asing, termasuk bahasa Inggris, juga sebagai alat bantu pengembangan bahasa Indonesia menjadi bahasa modern. Sejalan dengan fungsi kedua bahasa asing yaitu dalam pemanfaatan iptek, bahasa Inggris membantu menambah kosakata yang berhubungan dengan teknologi dan ilmu pengetahuan.

Selain itu, pemakaian Bahasa Inggris meluas hingga ke berbagai bidang seperti pendidikan, perdagangan, ekonomi dan bisnis, pariwisata dan hospitality termasuk kegiatan perhotelan dan kuliner, dan media masa. Namun, pemakaian bahasa Inggris dalam bidang-bidang tersebut bervariasi intensitasnya. Kecenderungan terakhir dalam beberapa bidang menunjukkan pemakaian yang lebih besar dibandingkan sebelumnya, misalnya bidang pendidikan, yaitu melalui pendirian secara formal sekolah-sekolah menengah atas yang berdasarkan kepada kurikulum berbasis internasional yang mewajibkan bahasa Inggris sebagai bahasa pengantar pengajaran. Selain itu, dengan semakin berkembangnya bidang pariwisata dan hospitality, istilah-istilah yang umum digunakan dalam bahasa Inggris untuk bidang ini, khususnya perhotelan dan kuliner, menjadi bahasa yang umum pula digunakan ketika berkomunikasi, terutama lisan, tanpa terjemahan dan penjelasan dalam Bahasa Indonesia. Media masa pun menjadi wahana efektif dalam memperkenalkan kepada masyarakat berbagai istilah asing (Bahasa 
Inggris) yang belum ada padanannya dalam bahasa Indonesia. Penggunaannya pun seolah-olah bukan bahasa asing seperti kata-kata selular, handphone, breaking news, broadcasting, entertainment, dan sebagainya.Pada umumnya masyarakat menganggap istilah itu sudah menjadi bagian dari ujaran sehari-hari.

\section{Pencampuradukan Bahasa Inggris dalam Bahasa Indonesia}

Pemakaian Bahasa Inggris yang digabungkan dengan Bahasa Indonesia dalam satu ujaran telah menggejala di kalangan masyarakat umum sejak sepuluh tahun yang lalu. Hal ini tergambar dalam kekhawatiran yang diungkapkan Assegaf (1999) tentang bahasa yang dipakai para jurnalis baik cetak maupun elektronik dalam menyajikan berbagai programnya; dan Munsyi (2005) juga mengkritik pencampuran kedua bahasa yang menghasilkan bahasa Indonesia yang campuraduk dalam berbagai bentuk komunikasi media seperti koran, majalah, dan televisi.

Assegaf (1999:210) menggambarkan keadaan pencampuradukan bahasa Inggris dalam bahasa Indonesia yang menghasilkan 'bahasa gado-gado' ini sebagai keadaan yang menyedihkan. Keadaan ini menyebabkan penurunan mutu dalam penggunaan bahasa Indonesia yang baku, walaupun tidak bermaksud untuk mendukung puritanisme bahasa Indonesia. Keadaan yang disorot oleh Assegaf (1999) tersebut umumnya terlihat dalam bahasa Indonesia yang digunakan oleh para penyiar radio dan televisi serta para wartawan media cetak. Lebih jauh ia mengkritisi peran para editor dan mungkin para pemimpin redaksi media masa yang tidak tanggap terhadap pencampuradukan yang dilakukan oleh para jurnalisnya.

Dengan semangat yang sama Munsyi (2005:31) menggambarkan keadaan ini sebagai 'penyakit nginggris' yang menyedihkan, menjengkelkan, bahkan menyebalkan. Gejala ini terlihat tidak hanya pada kalangan masyarakat umumnya dan para remaja tetapi juga pada kalangan pejabat dan pemimpin pemerintahan. Jika yang menggunakannya para remaja masih dapat dipahami sebagai salah bentuk pencarian identitas diri yang terjadi pada usia tersebut. Namun, jika para pejabat pemerintah baik pusat maupun daerah masih melakukannya sedangkan mereka diharapkan untuk lebih 'dewasa' dalam berbahasa maka keadaan ini menjadi bukti bahwa Bahasa Indonesia yang menjadi salah satu ciri bangsa Indonesia telah dirusak oleh bangsanya sendiri. Lebih jauh Munsyi (2005) menggambarkan keadaan bahasa 
Indonesia yang campuraduk, yang disebutnya sebagai bahasa 'capcay' atau bahasa 'tinutuan' selain bahasa 'gado-gado', tergambar dalam tulisan dan penamaan program-program televisi dan koran dalam bahasa Indonesia yang mempunyai juduljudul yang berbahasa Inggris.

Berdasarkan pengamatan penulis pada saat ini keadaan tidak berubah, bakan pencampuradukan ini mengalami peningkatan dalam setiap ujaran Bahasa Indonesia. Dengan kemajuan teknologi informasi dan komuni kasi dalam bentuk kemudahan mengakses berbagai informasi dari seluruh belahan dunia melalui Internet, masyarakat dapat dengan mudah mengetahui dan menyerap berbagai ilmu dan kebudayaan berbagai bangsa di dunia. Bahasa Inggris, sebagai satu-satunya bahasa pemersatu global (lingua franca) hingga saat ini, yang digunakan dalam komunikasi global tersebut, dengan sendirinya akan menjadi bagian yang wajar dalam setiap interaksi. Namun demikian, praktek pencampuradukan bahasa Inggris dalam Bahasa Indonesia dengan tingkat yang meluas dalam berbagai bidang tidak dapat dikatakan sebagai hal yang wajar. Penempatan yang semestinya setiap bahasa yang digunakan harus menjadi pertimbangan.

Ada bidang-bidang yang lebih erat dengan pemakaian Bahasa Inggris seperti bidang kuliner yang sangat erat dengan budaya Barat. Pada umumnya para koki utama (chef) ketika melakukan peragaan memasak mencampuradukkan bahasa Indonesia dengan bahasa Inggris dan kadang-kadang dengan bahasa Perancis, karena memang istilah-istilah tertentu masih dipahami oleh para koki ini dalam bahasa tersebut. Yang diungkapkan oleh para koki tersebut adalah satu atau dua kosa kata bahasa Indonesia, lima sampai sepuluh kosa kata bahasa Inggris, dan satu atau dua kosa kata bahasa Perancis. Keadaan ini akan sangat membingungkan bagi penonton atau pendengar yang tidak paham dengan baik kedua bahasa tersebut, walaupun pemahaman dapat dibantu dengan peragaan. Banyak istilah kuliner sebenarnya telah ada padanannya dalam bahasa Indonesia. Akan tetapi, dengan pertimbangan yang tidak jelas istilah itu tetap dipakai dalam bahasa aslinya, seperti ungkapan, "... sayuran ini kita chop..." atau "...kita pakai satu onion, yang kemudian kita slice..., lalu kita saute...". Padanan dalam bahasa Indonesia dengan arti yang sama akan menjadi seperti ini,"...sayuran ini kita potong-potong...", "... kita pakai satu bawang bombay, yang kemudian kita iris-iris..., lalu kita tumis...". Pertimbangan yang tepat 
kapan istilah-istilah dalam bahasa asing digunakan sesuai bahasa aslinya adalah usaha untuk menjadikan bahasa nasional sebagai bahasa yang menunjukkan identitas bangsa.

Munsyi (2005:38) melihat pencampuradukan bahasa Inggris ke dalam bahasa Indonesia ini sebagai "...penyakit remaja..." yaitu keadaan kebingungan dalam mencari identitas dan kepribadian yang kemudian pecah dan diekspresikan dengan cara yang "...aneh-aneh, kenes dan genit...". Ia menyebutnya sebagai 'nginggris', yaitu "...memasuk-masukan pelbagai kata, istilah, bahkan kalimat bahasa Inggris secara utuh, menurut ejaan baku yang berlaku di sana ke dalam bahasa resmi Indonesia...", yang membuat bangsa kita kebingungan untuk bisa menjadi bangsa yang berharkat oleh bahasa nasionalnya (Munsyi 2005:70-71). Namun, hal ini menurutnya tidak sama dengan kemampuan multilingual atau kemampuan berbahasa banyak yang terkait dengan kecendekiaan. Lebih jauh, jika berbicara mengenai kebudayaan nasional, tidak ada yang lebih tepat selain menyebut Bahasa Indonesia sebagai kebudayaan yang menyatukan suku-suku bangsa yang ada di Sabang sampai Merauke (Munsyi, 2005).

Gejala pemakaian bahasa yang bercampuraduk ini jelas bukan hasil dari pembelajaran. Interaksi langsung dengan bangsa-bangsa berbahasa Inggris, serta pengalaman pendidikan di negara-negara berbahasa Inggris kemungkinan besar berperan secara signifikan dalam membentuk kebiasaan berujar yang lebih mudah dalam bahasa Inggris. Tidak dapat dipungkiri bahwa penguasaan bahasa Indonesia masyarakat umumnya masih lemah; hal ini membuat mereka menjadi rentan terhadap pengaruh yang cukup kuat dari bahasa lain yang lebih mapan seperti bahasa Inggris. Selain itu, kontak budaya dalam berbagai bentuk melalui media terutama televisi yang umumnya mengedepankan budaya berbahasa Inggris memberi pengaruh besar terhadap anak-anak muda. Hal inilah yang kemudian membuat mereka berbicara menggunakan potongan-potongan ujarandan frasa bahasa Inggris semata-mata hanya untuk meningkatkan gaya hidup perkotaan. Namun, seperti yang dikhawatirkan oleh Assegaf (1999) dan Munsyi (2005), keadaan ini alih-alih memberi keuntungan malah menyebabkan berkurangnya kesadaran akan pemakaian bahasa Indonesia sebagai satusatunya bahasa nasional yang merupakan bahasa pemersatu (lingua franca) suku-suku bangsa di Indonesia atau merupakan bahasa komunikasi antaretnis. 


\section{Bahasa Inggris Sebagai Bahasa Kedua}

Selain kebutuhan komunikasi global dalam bahasa Inggris semakin bertambah seiring dengan semakin terbukanya hubungan antar negara di dunia, meningkatnya kecenderungan berbahasa Inggris seperti yang digambarkan sebelumnya memungkinkan pemakaian bahasa Inggris disamping pemakaian bahasa Indonesia dianggap sebagai sesuatu yang seharusnya terjadi. Maka akan sangat logis apabila muncul wacana tentang perlunya meningkatkan status bahasa Inggris menjadi bahasa kedua, seperti yang diusulkan oleh Gunarwan (1998 dalam Huda, 1999). Namun Huda (1999) berargumen bahwa hal ini akan bertentangan dengan kepentingan nasional yang lebih tinggi prioritasnya yaitu pengembangan bahasa Indonesia sebagai bahasa persatuan dan kesatuan nasional.

Di satu sisi pemakaian bahasa Inggris yang tinggi dalam interaksi dan komunikasi di berbagai bidang akan memudahkan komunikasi global. Hal in tentu akan membuat luasnya pergaulan internasional, mudahnya pemahaman dan penyerapan ilmu pengetahuan, yang sebagian besar diacu dari negara yang berbahasa Inggris, sehingga mampu mendukung perkembangan ilmu pengetahuan dan teknologi serta peningkatan kualitas pendidikan. Namun di sisi lain, ada pertanyaan tentang kualitas penguasaan bahasa Inggris yang memungkinkan untuk secara efektif mencapai fungsi yang diinginkan. Huda (1999) mengkhawatirkan hal ini terjadi karena pembelajaran bahasa Inggris sebagai bahasa asing wajib pun tidak menunjukkan hasil yang memuaskan.

Hal tersebut memang tidak mudah dan peningkatan status bahasa Inggris ini belum tentu menjadi penyelesaian dari masalah pencampuradukan bahasa Inggris ke dalam bahasa Indonesia; bahkan, sangat mungkin peningkatan status tersebut akan semakin meminggirkan status bahasa-bahasa etnis yang menjadi bahasa ibu atau bahasa kedua bagi sebagian besar penduduk Indonesia. Kehati-hatian ini sebenarnya wajar saja karena kita menginginkan bahasa Indonesia menjadi identitas bangsa. Jika bahasa Indonesia sudah mapan dan kuat dengan didukung oleh penguasaan bahasa daerah, peningkatan satus bahasa asing menjadi bahasa kedua seharusnya tidak akan menurunkan status bahasa Indonesia dan tidak mengecilkan arti bahasa daerah karena sudah mengakar, bahkan sebaliknya kemampuan berbahasa Inggris akan menguatkan daya komunikasi bangsa Indonesia dengan bangsa lain di dunia karena kemampuan 
berbahasa asingnya ditunjang oleh kemampuan berbahasa Indonesia dan bahasa daerah yang menjadi akar identitasnya. Dalam keadaan ini akan menjadi logis pula untuk mempertimbangkan suatu perencanaan bahasa yang menyeluruh yang dapat mengurai dan meluruskan kesemerawutan ini.

\section{Perencanaan Bahasa}

Perencanaan Bahasa (PB) adalah suatu usaha untuk memodifikasi tingkah laku linguistik suatu komunitas yaitu merencanakan dengan sengaja suatu keadaan di masa datang tentang pemakaian atau penghentian pemakaian suatu bahasa melalui peraturan dan hukum (Kaplan \& Baldauf, 1997). Jika kebijakan bahasa yang mela hirka n peraturan dan hukum dilakukan oleh pemerintah, PB dapat dilakukan oleh pemerintah (bersifat makro) dan pihak-pihak lain yang bukan pemerintah - termasuk individu (bersifat mikro) - seperti institusi pendidikan nasional dan swasta, badan-badan nonpemerintah, serta badan-badan swadaya masyarakat lainnya yang berhubungan dan peduli tentang pemakaian bahasa dalam masyarakat (Alwasilah, 2012; Kaplan \& Baldauf, 1997). Jadi, PB itu merupakan tanggung jawab semua pihak yang melihat kepentingan masyarakat yang lebih luas.

Walaupun tugas membuat kebijakan bahasa adalah pemerintah, implementasi dari kebijakan tersebut (berupa PB) dapat dilakukan oleh phak-pihak selain pemerintah. Selain itu, perlu dikaji mengapa PB perlu dilakukan dan bukan hanya sekedar menetapkan atau melarang pemakaian suatu bahasa, menetapkan bahasa apa yang diajarkan dan yang tidak boleh diajarkan. Yang perlu diperhitungkan adalah ekologi bahasa yang melihat bahasa tersebut mendapat dukungan secara luas oleh struktur budaya, pendidikan, sejarah, demografis, politis, dan sosial. Jika tidak diperhatikan, perencanaan yang dimasukkan ke dalam PB tidak akan mampu mendukung keberlangsungan perubahan bahasa tersebut (Kaplan \& Badauf, 1997).

\section{Perencanaan Bahasa di Beberapa Negara}

Pengalaman berbagai negara di Asia, seperti di Asia Tenggara dan Asia Timur, Afrika, dan Amerika Serikat menunjukkan bahwa kebijakan dalam menetapkan bahasa nasional dan perencanaan bahasa sangat dipengaruhi oleh faktor-faktor politik, sosial, ekonomi dan budaya. 


\section{Negara-negara Asia Tenggara}

Beberapa negara Asia Tenggara seperti Thailand dan Laos memperjuangkan penetapan bahasa nasional diantara berbagai bahasa etnik yang digunakan oleh masyarakatnya yang multietnik. Thailand menetapkan bahasa Thai sebagai bahasa nasional yang berlaku di seluruh negeri melalui keputusan pemerintah yang tegas setelah penanggulangan berbagai peristiwa sosial dan politis. Laos, yang merupakan negara tetangga Thailand, menetapkan bahasa nasional melalui keputusan yang dilakukan oleh pemerintah kolonial Perancis setelah mengkaji bahwa bahasa Lao adalah bahasa yang digunakan oleh kebanyakan masyarakat di Laos. Namun, dalam kenyataannya masyarakat Laos, yang juga masyarakat multietnis, tidak menggunakan bahasa Lao tetapi bahasa etnisnya masing-masing. Bahkan sebagian masyarakat yang secara geografis berdekatan dengan negara Thailand mendapat pengaruh yang kuat dari pemerintah Thailand yang turut memaksakan bahwa bahasa Thai tepat tuntuk Laos. Pada akhirnya pemerintah Laos tetap menentu kn bahwa Lao adalah bahasa nasional walaupun dalam kenyataannya bahasa Thai pun mempunyai pengaruh yang luas (Keyes, 2003).

Vietnam yang masyarakatnya juga multietnik, menetapkan bahasa Vietnam sebagai bahasa nasional, setelah sebelumnya - sebelum abad keduapuluh-bahasa yang digunakan adalah bahasa Cina dan Perancis. Selain menetapkan bahasa nasional, pemerinta h dengan dibantu Perancis dan Amerika menetapkan pula romanisasi dan sistem penulisan bahasa-bahasa dari sebagian besar kelompok-kelompok etnis yang tersebardi Vietnam. Pemeri ntah Vietnam juga mengusahakan pemertahanan bahasabahasa dari kelompoketnis yang lebih kecil, yang jarang dilakukan oleh pemerintah yang masyarakatnya multetnik. Namun, pemerintah tidak menindaklanjutinya dengan peningkatan status bahasa-bahasa tersebut sehingga dikhawati rkan akan hilang perlahanlahan karena kemungkinan akan kehilangan pembicara nya secara berta hap (Vasavakul, 2003). 


\section{Negara-negara Asia Timur}

Kebijakan bahasa di negara-negara Asia Timur da pat dilihat antara lain di Jepang, Korea, Cina, dan Taiwan. Jepang adalah negara yang dalam pembuatan kebijakan bahasa pada umumnya dilakukan secara tertutup sehingga tidak banyak diketahui. Akan tetapi, ada beberapakebijakan bahasa yangbersifat terbuka yaitu kebijakan tentang pemilihan huruf kanji yang dipakai, penyederhanaan sistem ejaan kana, dan penggunaan alphabet Romawi dalam ba hasa Jepang. Selain itu, oleh karena mempunyai penduduk yang mempunyai keku rangan pendengaran dengan jumlah yang cukupbanyak, pemerintah Jepang membuat kebijakan untuk mengadopsi bahasa isyarat sebagai bahasa yang dipakai disamping bahasa Jepang yang berlaku umumnya. Bahasa Inggris di Jepang tidak dianggap sebagai bahasa asing yang dipakai untuk komunikasi antar negara, tetapi sebagai bahasa lain yang harus dipelajari sesuai dengan aslinya. Keadaan ini telah menyebabkan kesulitan berkomuni kasi dalam bahasa Inggris bagi kebanyakan orang Jepang terutama dengan bangsa-bangsa lain selain bangsa penuturasli bahasa Inggris. Akan tetapi perkembangan varietas bahasa Inggris di antara Negaranegara di Asia, seperti perkembangan bahasa Inggris di Singapura, Malaysia, India, Filipina, dan Indonesia, kebijakan dila kukan terhadap pembelajaran bahasa Inggris yang tidak lagi puritandan terlalu sempurna (Honna, Tajima, dan Minamoto, 2000).

Lebih jauh, Honna, Tajima, dan Minamoto (2000) menyebutkan bahwa ada kebijakan bahasa penting yang dilakukan oleh pemerintah Jepang yaitu pemeliharaan dan restorasi terhadap bahasa dan budaya Ainu, yang merupakan bahasa dan budaya asli bangsa Jepang. Secara keseluruhan kebijakan bahasa di negara Jepang meperlihatkan kecenderungan yang lebih terbuka, dan mengakui keberagaman bahasa lokal disamping bahasa nasional yang menunjukkan bahwa Jepang pun ternyata adalah negara multilingual dan multikultural.

Di Korea penetapan bahasa nasional relatif tidak terlalu sulit karena bahasa Korea (Hangul) adalah bahasa yang digunakan oleh seluruh masyarakat di semenanjung Korea baik Utara maupun Selatan. Problem yang dihadapi adalah pengaruh huruf-huruf Cina pada bahasa tersebut yang sulit sekali dihilangkan karena sudah lama digunakan. Terlebih lagi ketika masa kolonial Jepang, bahasa Hangul ditekan pemakaian dan pembelajarannya sampai menjadi bahasa ketiga setelah Jepang dan Cina. Pada masa itu 
bahasa Jepang adalah bahasa nasional di Korea, akan tetapi setelah merdeka pada tahun 1930 bahasa Korea menjadi bahasa nasional (Shim dan Baik, 2000).

Kini, menurut Shim dan Baik (2000) bahasa Korea menghadapi problem dalam standardisasi karena pemakaian yang relative berbeda antara bahasa Korea yang dipakai di Utara dan yang dipakai di Selatan. Bahasa Korea yang dipakai di Selatan mengalami pengaruh yang signifikan dari bahasa Inggris baik secara sosial, linguistik maupun pendidikan, sedangkan yang dipakai di Utara lebih terisolasi dari pengaruh luar.

Cina mempunyai luas negara yang besar dengan banyaknya kebudayaan lokal dan bahasa kelompok-kelompok etnik. Namun pemerintah Republik Rakyat Cina dengan tegas dan keras menetapkan bahasa putonghua dan sistem penulisan bahasa Han sebagai bahasa nasional atau lingua franca di seluruh negeri. Pemerintah sangat kuat dalam menjaga kemurnian putonghua sehingga pemakaian bahasa-bahasa lokal kelompok minoritas ditekan (Dreyer, 2003a).

Taiwan adalah negara yang sebagian besar penduduknya berasal dari negeri Cina, atau disebut juga Cina daratan. Karena persoalan politik, Taiwan memisahkan diri dan membentuk negara demokrasi di luar Cina dengan haluan nasionalis. Oleh karena sebagian besar rakyat yang berpindah ke Taiwan berasal dari etnik Hokkien, penggunaan putonghua (yang disebut kuo-yu di Taiwan) menjadi berkurang karena pengaruh kultur etnis mereka. Setelah proses demokratisasi, bahasa-bahasa lain yang berkembang selain bahasa kuo-yu yang berasal dari Cina daratan mendapat perhatian besar dari pemerintah sehingga berdasarkan keadaan ini sangat mungkin untuk mengembangkan identitas Taiwan yang mandiri (Dreyer, 2003b).

\section{Negara-negaraAfrika}

Pengembangan kebijakan bahasa dan perencanaan bahasa di negara-negara Afrika pada akhir tahun 1980an mengalami hambatan yang berlapis dan cukup berarti (Chumbow, 1987). Problem yang dihadapi adalah kurangnya akhli professional dan model perencanaan yang efektif; kebijakan yang berlaku dikembangkan melalui caracara yang amatir seperti tidak didukung oleh data-data sosiolinguistik yang akurat, kurangnya bahkan hampir tidak ada dukungan pemerintah, kurangnya dana dalam perencanaan, dan terjadinya komplikasi dalam implementasi yang diakibatkan oleh tidak adanya perencanaan implementasi dan kurangnya koordinasi dalam pelaksanaan. 
Chumbow (1987) kemudian mengembangkan model perencanaan yang terdiri dari tiga tahap, yaitu tahap formulasi kebijakan yang terdiri atas pencarian data sosiolinguistik, keputusan tentang formulasi kebijakan, analisis ongkos dan keuntungan serta pengalokasian sumber-sumber daya, dan rencana pelaksanaan. Tahap kedua adalah implementasi kebijakan yang terdiri atas tahap standardisasi, termasuk rekayasa bahasa dan kodifikasi; dan tahap diseminasi kebijakan termasuk produksi bahan dan pendidikan. Tahap ketiga adalah pengakuan kebijakan secara efektif komunitas bahasa. Dalam setiap tahap, evaluasi selalu dilakukan sebelum tahap tersebut dimulai; ini menunjukkan kehati-hatian dalam melaksanakan setiap tahap yang harus selalu mempertimbangkan efisiensi dalam setiap langkah. Selain itu dalam langkah ketiga dilakukan untuk melihat tingkat pengakuan yang mungkin terjadi. Secara keseluruhan model ini menunjukkan pendekatan yang baik dan menyeluruh dengan pertimbangan keragaman bahasa etnik yang ada di negara-negara Afrika ini.

Kasus perencanaan bahasa di Negara Afrika Selatan setelah masa apartheid menjadi masalah politik dan tidak terlalu bersinggungan dengan masalah sosial dan ekonomi. Afrika Selatan pada masa pemisahan ras - apartheid - secara politik dari ras yang dominan, yaitu ras kulit putih, menggunakan bahasa Afrikaans sebagai bahasa umum, pemerintahan, dan ekonomi peradagangan. Kalaupun terjadi perencanaan bahasa yang dilakukan oleh Algemeen Beskaafde Afrikaans lebih diarahkan kepada penetapan untuk kepentingan agenda rasis dari kelompok penguasa yang terdiri dari kelompok kulit putih (Alexander, 2004).

Lebih jauh dikatakan, setelah pembebasan apartheid kebijakan bahasa resmi yang dipakai secara umum dan dalam kegiatan pemerintahan dan ekonomi belum tuntas karena masih terjadi perdebatan antara penggunaan bahasa Inggris yang didukung oleh kaum elit menengah kulit hitam dan bahasa-bahasa etnik yang sesuai dengan rasnya yang didukung oleh kelompok etnis nasionalis. Akan tetapi, kritik terhadap penggunaan bahasa etnik (Ngugi wa Thiong'o dalam Alexander, 2004) menunjukkan bahwa bahasa etnik ini sulit untuk digunakan sebagai bahasa utama karena sebagaian besar rakyat kulit hitam tidak percaya bahwa bahasanya itu dapat atau harus digunakan dalam tingkat yang lebih tinggi selain dari penggunaan dalam keluarga, komunitasnya, dan ritual keagamaan. Dengan demikian, hal ini menjadi kelemahan utama dari bahasa-bahasa etnik initerutamajika dibandingkan dengan bahasa Inggris. Pada akhirnya suatu dewan 
bahasa dibentuk, Pan South African Language Board (PANSALB) yang dalam tugasnya memberi masukan kepada pemerintah. Kebijakan yang dibuat PANSALB inimengarah kepada keadaan yang bertolak belakang dengan yang berkembang selama ini, yaitu dengan mempromosikan pemisahan penggunaan bahasa secara monolingual oleh masing-masing etnik secara berdampingan - vertically segregated multiple monolingualism - dan bukannya multi bahasa dengan kontak antar budaya secara horisontal-cross-cultural, horizontal multilingualism (Alexander, 2004:124). Namun demikian, PANSALB initelah menghasilkan capaian penting, antara lain membangun infrastruktur seperti mengembangkan unit leksikografi, membentuk panitia bahasa di provinsi,mendirikan dewan bahasa nasional, dan menyiapkan bank data. Kesemuanya ini sangat penting dalam perencanaan dan implementasi kebijakan bahasa.

\section{Negara Amerika Serikat}

Kebijakan dan perencanaan bahasa asing dari dua kasus di Amerika Serikat (AS) dapat memberi masukan tentang perencanaan bahasa yang mungkin bermanfaat bagi Indonesia. Kasus pertama adalah kebijakan pengajaran bahasa asing di Universitas Pennsylvania yang dapat mencerminkan sebuah perencanaan bahasa (Loheyde, 1993).

Dalam masyarakat AS yang multikultural, dengan sendirinya berbagai bahasa asing tumbuh dan mempunyai kelompok pemakainya. Loheyde (1993) menengarai keadaan ini tidak tercermin dalam kebijakan pendidikan bahasa asing di institusi perguruan tinggi di AS. Namun universitas Pennsylvania telah mengembangkan berbagai program bahasa asing di beberapa fakultas terutama Seni dan pendidikan, serta unit-unit lain seperti pusat bahasa. Hal ini disebabkan eksadaran akan pentingnya penguasaan bahasa asing bagi para mahasiswanya, selain merupakan kebijakan yang mengusung internasionalisasi universitas.

Secara keseluruhan langkah perencanaan bahasa yang diacunya dari model Fishman (Loheyde, 1993:118) sebagian besar telah memenuhi syarat sebagai perencanaan bahasa karena telah menetapkan tujuan dan arah pendidikan bahasa asing yang jelas, akan tetapi kebijakan ini tidak merinci kegiatan evaluasi yang seharusnya menjadi salah satu komponen dalam implementasi kebijakan. Evaluasi yang akan melihat apakah tujuan sudah tercapai sehingga hasil evaluasi dan rekomendasi dapat menjadi masukan dalam perencanaan berikutnya. Pada akhirnya, Loheyde (1993) 
cukup optimis dengan status perguruan tinggi yang dapat memikul tanggung jawab dalam memimpin AS menjadi negara yang mempunyai lingkungan multibahasa yang kondusif.

Kasus kedua adalah perencanaan bahasa asing pada tingkat perguruan tinggi di AS. Furumoto (1996) dengan pengamatan yang sama dengan Loheyde (1993) melihat bahwa masyarakat AS masih kurang kondusif terhadap keadaan multibahasa yang sebenarnya merupakan fakta dalam masyarakat yang multikultural. Akan tetapi, usaha pengajaran bahasa asing pada tingkat perguruan tinggi dapat dikatakan berhasil. Dengan pertimbangan kebutuhan akan penguasaan bahasa asing sebagai usaha merespon ekonomi global yang kompetitif, pemerintah AS mendirikan program pengajaran bahasa asing Lauder berdasarkan National Defense Education Act (NDEA). Tujuan program Lauder ini adalah penguasaan bahasa asing pada level tertinggi (advance) yang penting dan dibutuhkan dalam bidang bisnis dan manajemen . Dengan tujuan ini penyelenggara mengantisipasi bahwa kemampuan berbahasa asing pada tingkat tinggi akan dihargai dengan lebih baik oleh dunia bisnis oleh karenanya kemampuan ini merupakan aset bagi para mahasiswa dalam proses pelamaran kerja. Lebih jauh, pendirian program Lauder ini didasari dengan motivasi bahwa kemampuan berbahasa asing ini adalah sumber atau alat untuk melakukan bisnis dengan industri maupun masyarakat luar negeri.

Keberhasilan program ini terlihat dari salah satu laporan yang menggambarkan bahwa lulusan program Lauder ini dengan program internasionalnya telah menjadi lulusan sekolah bisnis yang paling dicari oleh perusahaan-perusahaan besar di dunia (Furumoto, 1996, mengutip International Business magazine, 1995). Pendirian program ini dapat dilihat sebagai kasus berhasil dalam perencanaan kultivasi penguasaan bahasa asing. Selain itu, program ini juga dianggap sebagai contoh dalam pengajaran bahasa asing yang berorientasi pada penggunaan, yang kemudian diikuti oleh beberapa asosiasi pengajaran bahasa asing lainnya.

Dari kasus-kasus beberapa negara tersebut, beberapa hal bisa kita pelajari. Pertama, peran dan intervensi pemerintah dalam penetapan bahasa sangat signifikan; kedua, perhatian dan pertimbangan keberagaman bahasa etnik yang berkembang di masyarakat memungkinkan bahasa yang dipilih dapat diterima walaupun dalam 
pemakaiannya masih bercampur dengan bahasa daerah. Ketiga, peran pemerintah atau badan/dewan yang berwibawa sangat signifikan terutama dalam penelitian, perencanaan implementasi kebijakan bahasa. Selain itu, badan yang berwibawa mampu memberikan masukan yang berkualitas kepada pemerintah. Keempat, peran perguruan tinggi cukup signifikan dalam perencanaan dan pengelolaan pemakaian bahasa asing,akan tetapi inisiatif dan inetervensi tetap harus dilakukan oleh pemerintah dalam menetapkan dan mengakui program-program yang dilaksanakan oleh perguruan tinggi.

\section{Pertimbangan Perencanaan Bahasa Inggris di Indonesia}

Bahasa Indonesia sebagai bahasa nasional pemersatu kelompok-kelompok etnis yang ada di Indonesia dan sekaligus juga sebagai lingua franca dalam komunikasi antaretnis tersebut telah menjadikan bahasa Indonesia sebagai satu-satunya bahasa resmi yang digunakan dalam masyarakat yang pluralistik secara sosiolinguistik (Renandya, 2000). Sebenarnya, berbagai bahasa asing yang pernah ada di Indonesia memberikan pengaruh yang signifikan pada bahasa Indonesia (Munsyi, 2005) yang pada dasarnya adalah bahasa Melayu. Sebagai bahasa perdagangan, bahasa Cina dan Portugis memberikan pengaruh kosakata. Demikian pula dengan bahasa Arab; selain sebagai bahasa perdagangan juga sebagai bahasa agama Islam. Bahasa Belanda sebagai bahasa yang dominan pada zaman kolonial juga memberikan pengaruh terutama pada bidang pemerintahan dan hukum.

Bahasa Inggris sebagai bahasa asing utama memberikan pengaruh yang tidak sedikit terutama pada bidang ilmu dan teknologi. Keseluruhan pengaruh ini umumnya berupa pemakaian kata-kata baik berupa perubahan ejaan ke dalam bahasa Indonesia, seperti kata 'manajemen' dari bahasa Inggris 'management'; atau perubahan bunyi pada kata bahasa Inggris 'blazer' yang menjadi 'bleser' dalam pengucapan bahasa Indonesia. Semua pengaruh ini memperkaya kosakata serapan dalam bahasa Indonesia, yang juga menyerap kata-kata dari berbagai bahasa daerah (Bertrand, 2003) yang ada di Indonesia, seperti kata 'pemirsa' dari bahasa Jawa atau 'kuasa' dari bahasa Sunda.

Dalam deklarasi kebijakan bahasa tahun 1999(Alwi \& Sugono, 2003:230) setelah meninjau ulang kebijakan bahasa tahun 1975, disebutkan bahwa bahasa Indonesia 
bersifat "...terbuka terhadap pengaruh teknologi dan informasi dan penggunaan bahasa asing, terutama Bahasa Inggris, di dalam pergaulan internasional...". Hal ini menunjukkan bahwa pengaruh bahasa-bahasa tersebut ke dalam bahasa Indonesia adalah hal yang diterima secara formal dan diharapkan terutama untuk kelancaran komunikasi antarbangsa. Lebih jauh dinyatakan dalam deklarasi tersebut bahwa bahasa Inggris sebagai salah satu bahasa asing diutamakan untuk menjadi sumber pengembangan bahasa Indonesia; dan oleh karena penggunaannya yang semakin meningkat baik untuk keperluan pemerintahan maupun dunia usaha, dimunggkinkan untuk perumusan kembali kedudukan bahasa asing tersebut beserta dengan pengajarannya (Alwi \& Sugono, 2003).

Pemerintah melalui lembaga-lembaga resmi seperti Pusat Bahasa atau lembagalembaga lain yang non-pemerintah dapat melakukan PB. Baldauff (2005) menyatakan bahwa PB pada dasarnya terdiri atas penetapan kebijakan bahasa dan implementasinya berupa perencanaan bahasa. Jadi yang dapat dilakukan oleh lembaga-lembaga tersebut adalah merupakan implementasi dari kebijakan bahasa pada tahun 1999 tersebut di atas. Lebih jauh Baldauf (2005 dan 2012) menyebutkan ada empat jenis PB, yaitu perencanaan pemakaian bahasa (status planning), perencanaan bentuk bahasa (corpusplanning), perencanaan pembelajaran bahasa (language-in-ed ucation planning), dan perencanaan promosi bahasa (image/prestige planning). Dari keempat jenis PB tersebut yang dapat dilakukan bisa menyangkut perencanaan pemakaian bahasa dan perencanaan imaji atau prestige dari bahasa asing yang menempati kedudukan bahasa asing utama. Namun demikian, seperti yang diingatkan oleh Kaplan (2013) bahwa PB erat kaitannya dengan kondisi sosiopolitik dan persepsi para pemegang pemerintahan serta pelaksana perencanaan, dan bukan semata-mata karena pertimbangan linguistik atau kebutuhan pemakai bahasa. Dengan demikian, aktivitas PB perlu dilakukan oleh lembaga yang pengelolanya adalah orang yang memahami kelemahan ini dan bukan semata-mata mempraktekkan kebijakan dari atas ke bawah dan memaksakan kehendak.

Pengaruh yang cenderung mencampuradukan pemakaian bahasa, baik bahasa Inggris maupun bahasa daerah tertentu, menjadi kecenderungan yang tidak bisa diabaikan karena berkembang di antara pemakai bahasa Indonesia dengan kecepatan dan tingkat yang cukup tinggi,dan menjadi kecenderungan yang secara bertahap terus terjadi dan menjadi akumulasi selama lebih dari sepuluh tahun hingga saat ini (lihat 
Assegaf, 1999; Munsyi, 2005). Bahkan pencampuradukan bahasa ini ditengarai terjadi pula dalam pemakaian bahasa di kalangan pemerintahan (lihat Bertrand, 2003). Jika tidak dilakukan intervensi dalam bentuk apa pun, hal ini akan menjadi suatu bentuk bahasa dengan kelompok pemakai tertentu. Varian dari bahasa lain selain bahasa nasional akan berbentuk bahasa yang bersifat lebih mudah dipakai oleh masyarakat dan pada akhirnya akan lebih disukai untuk digunakan. Dengan mengingat bahwa bahasa juga merupakan lambang dari identitas suatu kelompok dan merepresentasikan bahasa nasional (lihat McRobbie-Utasi, n.d. dan Bertrand, 2003), perubahan dalam pemakaian bahasa ini tentu akan mengancam identitas bangsa.

\section{PENUTUP}

Fungsi bahasa Inggris dalam masyarakat Indonesia sebagai bahasa asing utama yang digunakan selain dalam pergaulan internasional adalah juga sebagai sumber pengembangan ilmu dan teknologi dan pengembangan bahasa Indonesia sendiri dinyatakan dalam kebijakan politik bahasa (lihat Alwi \& Sugono, 2003). Akan tetapi kedudukan yang menempatkan bahasa Inggris sebagai bahasa asing yang mempunyai peran dalam komunikasi hampir di seluruh aspek kehidupan ini seharusnya tidak dianggap sebagai pengaruh yang akan merusak pemakaian bahasa Indonesia sehingga himbauan untuk pembenahan yang menyeluruh perlu dilakukan (lihat Assegaf, 1999). Dalam pemakaian bahasa-bahasa tersebut perlu dorongan dan contoh dari berbagai pihak seperti pemerintah dan lembaga-lembaga bahasa termasu $\mathrm{k}$ institusi pend idikan agar menggunakan bahasa yang tepat untuk situasi yang sesuai. Oleh karenanya diperlukan kebijakan bahasa yang meninjau dan menata ulang praktek pemakaian bahasa ini agar apa yang berkembang dan pengaruh signifikan dari bahasa daerah dan bahasa asing lainnya dapat memberikan manfaat yang lebih baik lagi untuk perkembanga $n$ bahasa Indonesia.

\section{UCAPAN TERIMA KASIH}

Penulis ingin menyampaikan terima kasih kepada Prof. Dr. A. Chaedar Alwasilah, Universitas Pendidikan Indonesia, atas dukungan dan apresiasinya terhadap kajian ini. 


\section{DAFTAR PUSTAKA}

Alwasilah, A.C. (2012). Pokoknya Rekayasa Literasi. Band ung: PT Kiblat Bu ku Utama.

Alwi, H. dan Sugono, D. (2003). Politik Bahasa. Risalah Seminar Politik Bahasa. Cetakan 2. Jakarta: Progress.

Alexander, N. (2004). The Politics of Language Planning in Post-apartheid South Africa. Language Problems \& Language Planning, 28, 2, 113-130.

Assegaf, D.H.(1999). Bahasa Koran, Radio, dan Televisi Perlu Pembenahan Menyeluruh dalam Alwi, H. dan Sugono, D. (2003). Politik Bahasa. Risalah Seminar Politik Bahasa. Cetakan 2. Jakarta: Progress.

Baldauf, R.B. (2005). Language Planning and Policy: Recent Trends, Fut ure Directions, diunduh dari espace.library.uq.edu.au pada tanggal 17 Juni 2013.

(2012). Introduction: Where have we been? Where we might be going? RBLA. Belo Horizonte, 12, 21 233-248.

Bertrand, J. (2003). Language Policy and the Promotion of National Identity in Indonesia, dalam Brown, M.E. \& Ganguly, S. (2003). Fighting Words. Language Policy and Ethnic Relations in Asia. Massachusetts: The M IT Press.

Chumbow, B.S. (1987). Towards a La nguage Planning Model for Africa. Journal of West African Languages, XVII, 1, 15-22.

Dreyer, J.T. (2003a). The Evol ution of La nguage Policies in China dala m Brown, M.E. \& Gangul y, S. (2003). Fighting Words. Language Policy and Ethnic Relations in Asia. Massachusetts: The MIT Press.

(2003b). The Evolution of La nguage Policies and National Identity in Taiwan dalam Brown, M.E. \& Ganguly, S. (2003). Fighting Words. Language Policy and Ethnic Relations in Asia. Massachusetts: The MIT Press.

Furumoto, M.A. (1996). Foreign La nguage Planning in U.S. H igher Ed ucation: The Case of a Graduate Business Program. Working Paper in Educational Linguistics, 12, 2, 29-42.

Huda, N. (1999). Kedudukan dan Fungsi Bahasa Asing dalam Alwi H. dan Sugono, D. (2003). Politik Bahasa. Risalah Seminar Politik Bahasa. Cetakan 2. Jaka rta: Progress. 
Kaplan, R.B. (2013). Language Planning. Applied Research on English Language, 2, 1, $1-12$.

Kaplan, R.B. \& Baldauf, R.B. (1997). Language Planning.From Practice to Theories.

Clevedon: Multilingual Matters, Ltd.

Keyes, C.F. (2003). The Politics of Language in Thailand and Laos, dalam Brown, M.E. \& Ganguly, S. (2003). Fight ing Words. Language Policy and Ethnic Relations in Asia. Massachusetts: The MIT Press.

Kirkpatrick, A. dan Sussex, R. (2012). Eds. English as an International Language in Asia: Implications for Language Education. Dordrecht: Springer Science + Business Media.

Loheyde, K.I. (1993). Foreign Language Teaching at the University of Pennsylvania: $A$ language planning case study. Working Paper in Educat ional Lingu ist ics, $9,1,105-126$.

McRobbie-Utasi,Z. (n.d.). Language Planning, Literacy and Cultural Identity: The Skolt Sami Case, diunduh dari www.sfu.caL-mcrobbie/SamiLit(SY-mP-..jpdf tanggal 17 Juni 2013.

Munsyi, A.O. (2005). Bahasa Menunjukkan Bangsa. Jakarta: Kepustakaan Populer Gramedia.

Renandya, W.A. (2000). Indonesia dalam Kam, H. W. dan Wong,R.Y.L. (2000). Language Policies and Language Education. Editors. Singapore: Times Academic Press.

Shim, R.J. dan Baik, M.J. (2000). Korea (South and North) dalam Kam, H. W. dan Wong, R.Y.L. (2000). Language Policies and Language Education. Editors. Singapore: Times Academic Press.

Vasavakul,T. (2003). Language Policy and Ethnic Relations in Vietnam dalam Brown, M.E. \& Ganguly, S. (2003). Fighting Words. Language Policy and Ethnic Relations in Asia. Massachusetts: The MIT Press. 